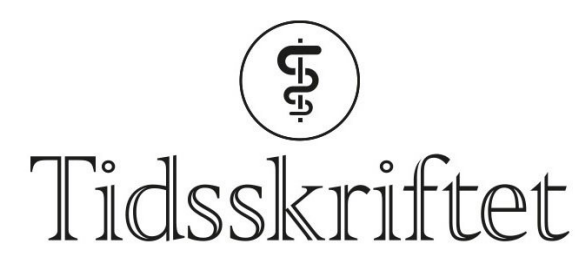

DEN NORSKE LEGEFORENING

\title{
Hva med litt alger?
}

KOMMENTAR

\section{KIRSTEN OSTY}

E-post: osty@orange.fr

Ingen oppgitte interessekonflikter.

Hvis vi mangler jod er vel ikke nødvendigvis melk, fisk eller salt tilsatt jod den beste løsning (1). Jeg har selv nettopp fått konstatert et vel lavt nivå. Og fikk råd av min lege og nutriterapeut å spise mer alger. Med den kysten vi har hadde det vært interessant (har lenge vært mitt ønske) å lære om hvilke arter vi helst kan spise. Hvorfor ikke lage algeprodukter til salg? Vi kan jo også kjøpe i helsekostbutikker. Deilig på salaten for eksempel.

\section{LITTERATUR:}

1. Henjum S, Abel MH, Meltzer HM et al. Er inntaket av jod i befolkningen tilstrekkelig? Tidsskr Nor Legeforen 2019; 139. doi: 10.4045/tidsskr.18.0319. [PubMed][CrossRef]

Publisert: 11. mars 2019. Tidsskr Nor Legeforen. DOI: 10.4045/tidsskr.19.0154

(C) Tidsskrift for Den norske legeforening 2020. Lastet ned fra tidsskriftet.no 